ISSN: 1896-4087

DOI: http://dx.doi.org/10.21784/ZC.2018.003

JADWIGA KOPEĆ

Uniwersytet Adama Mickiewicza w Poznaniu Uniwersytet Europejski Viadrina we Frankfurcie nad Odrą

\title{
„Ponaglenie” - nowa instytucja w Kodeksie postępowania administracyjnego służąca przeciwdziałaniu bezczynności organów administracji publicznej i przewlekłości postępowania administracyjnego
}

\author{
„Reminder" - a new legal instrument in the Code of \\ Administrative Procedure to eliminate inaction of public \\ administration authorities and the excessive lengths \\ of the administrative proceedings
}

\section{Streszczenie:}

Celem niniejszego artykułu jest ocena aktualnych regulacji Kodeksu postępowania administracyjnego ${ }^{1}$ służących przeciwdziałaniu bezczynności organów i przewlekłości postępowania administracyjnego. W ramach rozważań zaprezentowana zostanie nowa instytucja - „ponaglenie”, która została wprowadzona do k.p.a. nowelizacją z dnia 7 kwietnia 2017 r. Nowy instrument ma na celu ulepszenie procedury administracyjnej oraz skrócenie czasu jej trwania.

Słowa kluczowe: bezczynność organu, przewlekłość postępowania administracyjnego, ponaglenie, nowelizacja Kodeksu postępowania administracyjnego

\footnotetext{
${ }^{1}$ Ustawa z dnia 14 czerwca 1960 r. (tekst jedn. Dz.U. z 2017 r., poz. 1257 ze zm.), dalej: k.p.a.
} 
Jadwiga Kopeć - „Ponaglenie” - nowa instytucja w Kodeksie...

\begin{abstract}
:
The purpose of the article is the assessment of actual regulations of the Code of Administrative Procedure that are to serve the elimination of inaction of public administration authorities and the excessive length of the administrative proceedings. The author presents a new legal instrument - „Reminder”, introduced by an amendment of 7th April 2017 to the Polish Code of Administrative Procedure. The new legal instrument should improve the administrative proceedings and shorten their duration.
\end{abstract}

Keywords: inaction of authority, excessive length of administrative proceedings, reminder, amendment of the Code of Administrative Procedure

\title{
Wprowadzenie
}

Jednym z najistotniejszych zagadnień z punktu widzenia jednostki, która domaga się ochrony swych praw przed organami administracji publicznej jest szybkość postępowania. Treść i zakres tej zasady są od wielu lat przedmiotem dyskusji zarówno w doktrynie jak i w orzecznictwie sądów administracyjnych. Szybkość postępowania administracyjnego i terminowe załatwianie spraw jest bolączką organów prowadzących sprawy administracyjne, dlatego konieczne stało się wprowadzenie do systemu prawa odpowiednich środków służących dyscyplinowaniu organów.

Jednym z naczelnych celów omawianej nowelizacji postępowania administracyjnego było znalezienie optymalnego modelu regulującego zwalczanie opieszałości organów i przyspieszenie postępowań, co znalazło aprobatę w doktrynie, która również wskazywała na problemy w tym zakresie ${ }^{2}$. Skutkiem takiego zamysłu ustawodawcy było wprowadzenie ustawą z dnia 7.04.2017 r. o zmianie ustawy - Kodeks postępowania administracyjnego ${ }^{3}$ modyfikacji w zakresie środka służącego obronie przed bezczynnością lub przewlekłością postępowania. Istniejące dotychczas zażalenie $\mathrm{z}$ art. 37 k.p.a. zostało zastąpione nowym instrumentem prawnym - ponagleniem. Wzorem dla takiej zmiany było

\footnotetext{
${ }^{2}$ Por. np. W. Gurba, Zwalczanie i zapobieganie bezczynności oraz przewlekłości postępowania, „Państwo i Prawo” 2015, nr 11, s. 94-110; Z. Kmiecik, M. Kotulska, Jeszcze o rodzajach opieszałości organów administracji publicznej w ogólnym postępowaniu administracyjnym, „Samorząd Terytorialny” 2017, nr 1-2, s. 94-108.

${ }^{3}$ Dz.U., poz. 935, dalej: ustawa z 7.04.2017 r.
} 
rozwiązanie istniejące dotychczas na gruncie Ordynacji Podatkowej ${ }^{4}$, która pozwala na użycie ponaglenia jako środka służącego ochronie materialnych interesów podatnika oraz praw strony w toczącym się postępowaniu w przypadku uchybienia terminu załatwienia sprawy ${ }^{5}$.

Jak wskazano w uzasadnieniu projektu ustawy z 7.04.2017 r. zażalenie jest środkiem właściwym do zaskarżania czynności organu, nie zaś zachowań mających postać zaniechania 6 . Kwestia ta była dotychczas szeroko komentowana w literaturze, która określała zażalenie na bezczynność lub przewlekłość jako specyficzny środek prawny, odrębny od przewidzianego $\mathrm{w}$ art. 141-144 k.p.a ${ }^{7}$. W związku z tym, ustawodawca w poszukiwaniu optymalnej nazwy postanowił odrzucić zażalenie jako nietrafne w kontekście zwalczania przewlekłości lub bezczynności i w celu zapewnienia większej klarowności i spójności regulacji ${ }^{8}$ zdecydował się na postulowane przez doktrynę ponaglenie ${ }^{9}$.

\section{Zakres przedmiotowy ponaglenia}

Ponaglenie zdaniem ustawodawcy ma służyć zasygnalizowaniu organowi prowadzącemu postępowanie, iż narusza on zasady terminowego załatwiania spraw. Jak wskazano w uzasadnieniu nie ma ono charakteru środka zaskarżenia w ścisłym tego słowa znaczeniu ${ }^{10}$. Należy więc zgodzić się, że jego zadaniem jest zweryfikowanie, czy organ

\footnotetext{
${ }^{4}$ Por. art. 141 ustawy z dnia 29 sierpnia 1997 r. Ordynacja podatkowa (tekst jedn. Dz.U. z 2017 r., poz. 201 ze zm.).

${ }^{5}$ M. Miłosz, Bezczynność organu administracji publicznej w postępowaniu administracyjnym, Warszawa 2011, s. 92.

${ }^{6}$ Uzasadnienie rzq̨dowego projektu ustawy o zmianie ustawy Kodeks postępowania administracyjnego oraz niektórych innych ustaw, Sejm VIII Kadencji, druk sejmowy nr 1183, http://www.sejm.gov.pl/Sejm8.nsf/druk.xsp?nr=1183, [dostęp: 08-04-2018].

${ }^{7}$ Por. np. A. Kraczkowski, [w:] R. Hauser, M. Wierzbowski, Kodeks postępowania administracyjnego. Komentarz, Warszawa 2015, art. 37; B. Adamiak, J. Borkowski, Kodeks postępowania administracyjnego. Komentarz, Warszawa 2016, art. 37.

${ }^{8}$ Uzasadnienie..., Sejm VIII Kadencji, druk sejmowy nr 1183.

${ }^{9}$ Por. np. W. Gurba, Zwalczanie i zapobieganie..., op. cit., s. 97; J. P. Tarno, Zażalenie i skarga na bezczynność organu (cz.1), „Fiskus 2006”, www.e-podatnik.pl/artykul/ fiskus/8767/Zazalenie_i_skarga_do_sadu_administracyjnego_na_bezczynnosc_organu_cz_Ihtml [dostęp: 16-09-2017].

${ }^{10}$ Uzasadnienie..., Sejm VIII Kadencji, druk sejmowy nr 1183.
} 
Jadwiga Kopeć - „Ponaglenie” - nowa instytucja w Kodeksie...

dopuścił się w swoim działaniu opieszałości ${ }^{11}$. Znowelizowany art. 37 $\S 1$ k.p.a. stanowi expressis verbis, iż stronie służy prawo do wniesienia ponaglenia w obu przypadkach opieszałości organu - tj. bezczynności, jak i przewlekłości.

Brak legalnych definicji tych pojęć budził, do czasu wejścia w życie ustawy z 7.04.2017 r., szerokie wątpliwości interpretacyjne zarówno w doktrynie, jak i w orzecznictwie. Rozgraniczenie obu pojęć wprowadzone do k.p.a. w 2011 r. ${ }^{12}$ pozwoliło wyróżnić dwie odrębne sytuacje procesowe zaistniałe $\mathrm{w}$ sprawie administracyjnej ${ }^{13}$, jednak sposób uregulowania tych kwestii został w literaturze skrytykowany ${ }^{14}$. Przedstawiciele doktryny stawiali zasadnicze pytanie o celowość wprowadzonego rozgraniczenia, jak również wskazywali liczne usterki legislacyjne ${ }^{15}$. Brak zdefiniowania pojęć bezczynności i przewlekłości wymusił na sądach administracyjnych dokonywanie interpretacji na podstawie konkretnych przypadków, tak więc to orzecznictwo wypełniło wprowadzone przez ustawodawcę pojęcia treścią ${ }^{16}$.

W orzecznictwie Naczelnego Sądu Administracyjnego przyjęto, iż o bezczynności organu można mówić nie tylko wtedy, gdy w ustalonym prawem terminie organ administracji publicznej nie podjął żadnych

${ }^{11}$ A. Kraczkowski, [w:] R. Hauser, M. Wierzbowski, Kodeks postępowania administracyjnego. Komentarz, Warszawa 2017, art. 37 nb. 5.

12 Zob. ustawa z dnia 3 grudnia 2010 r. o zmianie ustawy - Kodeks postępowania administracyjnego oraz ustawy - Prawo o postępowaniu przed sądami administracyjnymi (Dz.U. z 2011 r. Nr 6, poz. 18 ze zm.).

${ }^{13}$ B. Adamiak, J. Borkowski, Kodeks postępowania administracyjnego. Komentarz, Warszawa 2016, art. 37, nb. 5.

${ }^{14}$ Por. np. W. Chróścielewski, Opinia dotycząca projektu ustawy o zmianie ustawy - Kodeks postępowania administracyjnego oraz ustawy - Prawo o postępowaniu przed sq̨dami administracyjnymi (druk sejmowy nr 2987), Biuro Analiz Sejmowych, http:// orka.sejm.gov.pl/rexdomk6.nsf/Opdodr?OpenPage\&nr=2987, [dostęp: 08-04-2018].

15 Por. np. Z. Kmieciak, Przewlekłość postępowania administracyjnego, „Państwo i Prawo" 2011, nr 6, s. 33 i 34; A. Korzeniowska-Polak, Zażalenie na przewlekłość postępowania administracyjnego, [w:] M. Błachucki, T. Górzyńska, G. Sibiga, Analiza i ocena zmian kodeksu postępowania administracyjnego w latach 2010-2011, Warszawa 2012, s. 127 i n.; M. Szalewska, Bezczynność organu, a przewlekłość postępowania administracyjnego - o próbie rozróżnienia pojęć, „Administracja. Teoria-Dydaktyka-Praktyka” 2013, nr 3, s. 52 i n.

16 Ł. Sadkowski, Zmiany w Kodeksie postępowania administracyjnego, Warszawa 2017, s. 28. 
czynności, do których był zobowiązany, ale także wówczas, gdy prowadził postępowanie w sprawie, lecz nie zakończył go w terminie wydaniem stosownego rozstrzygnięcia ${ }^{17}$. Prowadziło to do wniosku, iż za bezczynność organu należało uznawać brak działania organu jak i odmowę wydania określonej decyzji ${ }^{18}$. Zarzut przewlekłego prowadzenia postępowania można było postawić zaś w sytuacji, gdy postępowanie prowadzono w sposób nieefektywny, będący skutkiem wykonywania czynności w dużym odstępie czasu bądź wykonywanie czynności pozornych, powodujących, że formalnie organ nie jest bezczynny, ewentualnie mnożenie przez organ czynności dowodowych ponad potrzebę wynikającą z istoty sprawy ${ }^{19}$. Takie rozróżnienie spowodowało, iż organy prowadząc postępowanie powinny bardzo rygorystycznie podchodzić do zasady szybkości postępowania, ponieważ nawet formalne nieprzekraczanie terminu załatwienia sprawy mogło je narazić na kontrolę pod kątem celowości i przydatności działań, czemu służyła konstrukcja przewlekłości postępowania ${ }^{20}$. W takiej sytuacji organowi, który nie dopuszczał się bezczynności, wręcz przeciwnie - był nadaktywny w swoich działaniach, również można było zarzucić prowadzenie postępowania w sposób przewlekły ${ }^{21}$.

Nowelizacją z 7.04.2017 r. ustawodawca zdefiniował w art. 37 $\S 1$ k.p.a. te dwie instytucje wskazując, że bezczynność to niezałatwienie sprawy w terminie określonym $w$ art. 35 k.p.a. lub przepisach szczególnych oraz w terminie nowym wskazanym w zawiadomieniu o niezałatwieniu sprawy w terminie, zaś przewlekłość to prowadzenie postępowania dłużej niż jest to niezbędne do załatwienia sprawy. Wprowadzone definicje mają bardzo ogólny charakter, jednak zostały oparte na dorobku orzecznictwa sądów administracyjnych, co

\footnotetext{
${ }^{17}$ Por. Wyrok Naczelnego Sądu Administracyjnego z 14.09.1986 r., SAB/Kr 22/86, CBOSA.

${ }^{18}$ J. Olszanowski, [w:] R. Hauser, A. Skoczylas, Postępowania administracyjne i sądowoadministracyjne z kazusami, Warszawa 2016, s. 76.

${ }^{19}$ Wyrok Naczelnego Sądu Administracyjnego z 27.08.2013 r., II OSK 549/13, CBOSA.

${ }^{20}$ R. Kędziora, Kodeks postępowania administracyjnego. Komentarz, Warszawa 2014, Art. 37 nb. 2.

${ }^{21}$ W. Gurba, Zwalczanie i zapobieganie..., op. cit., s. 97.
} 
Jadwiga Kopeć - „Ponaglenie” - nowa instytucja w Kodeksie...

powoduje, że nie traci ono swej aktualności w zakresie skarg na bezczynność i przewlekłość postępowania ${ }^{22}$.

Podkreślenia wymaga fakt, iż takie ustawowe rozgraniczenie i zdefiniowanie pojęć bezczynności i przewlekłości ma duże znaczenie dla możliwości złożenia przez stronę ponaglenia. Klarowne przedstawienie kryteriów prawnych rozróżniających te dwie sytuacje procesowe ułatwi bowiem stronie formułowanie argumentacji w uzasadnieniu ponaglenia ${ }^{23}$. Z drugiej strony jest odpowiedzią na oczekiwania płynące od przedstawicieli doktryny i praktyki.

\section{Warunki formalne i tryb wniesienia ponaglenia}

Ponieważ dotychczasowy sposób wnoszenia zażalenia na bezczynność lub przewlekłość powodował wiele wątpliwości, m.in. w sytuacji gdy kwestionowano zachowanie organu, który nie miał nad sobą organu wyższego stopnia ${ }^{24}$, ustawodawca zdecydował się na uproszczenie i usprawnienie modelu zaskarżalności opieszałości organów ${ }^{25}$.

Kwestią zasadniczą $\mathrm{w}$ ramach przesłanek formalnych jest ustalenie, jakie podmioty są uprawnione do skorzystania z instytucji ponaglenia. Legitymację do wniesienia ponaglenia posiada strona lub organizacja społeczna działająca na prawach strony albo prokurator lub Rzecznik Praw Obywatelskich (zob. art. $31 \S 3$ k.p.a.) ${ }^{26}$. Ponaglenie może zostać skierowane zarówno do organu prowadzącego postępowanie w pierwszej instancji, jak i do organu prowadzącego postępowanie odwoławcze, ponieważ terminy załatwiania spraw określone w art. 35 i 36 k.p.a. odnoszą się także do postępowania w drugiej instancji ${ }^{27}$. Możliwość

\footnotetext{
${ }^{22}$ Uzasadnienie..., Sejm VIII kadencji, druk sejmowy nr 1183.

${ }^{23}$ B. Adamiak, J. Borkowski, Kodeks postępowania administracyjnego. Komentarz, Warszawa 2017, art. 37, nb. 5.

${ }^{24}$ Por. W. Piątek, Wezwanie do usunięcia naruszenia prawa w postępowaniu sądowoadministracyjnym, „Przegląd Sądowy” 2013, z. 9, s. 43-61.

${ }^{25}$ Ł. Sadkowski, Zmiany w Kodeksie..., op. cit., s. 31.a

${ }^{26}$ B. Adamiak, J. Borkowski, Kodeks postępowania administracyjnego. Komentarz, Warszawa 2017, art. 37, nb. 2.

${ }^{27}$ P. M. Przybysz, Kodeks postępowania administracyjnego. Komentarz, Warszawa 2017, art. 37, nb. 10.
} 
skorzystania z ponaglenia aktualizuje się w momencie zaistnienia stanu bezczynności organu lub przewlekłości postępowania ${ }^{28}$. Podkreślenia wymaga, iż o ile do stwierdzenia, że organ jest bezczynny stosuje się przesłanki obiektywne wynikające z ustawowych terminów załatwiania spraw, to w przypadku zarzutu przewlekłego prowadzenia postępowania należy odnieść się do subiektywnego przekonania strony, iż doszło do naruszenia dyrektywy załatwiania spraw bez zbędnej zwło$\mathrm{ki}^{29}$. Kolejną przesłanką formalną jest spełnianie przez ponaglenie warunków przewidzianych przepisami prawa dla podania, co do treści, jak i co do formy (art. 63 k.p.a.) $)^{30}$. Szczególnym wymogiem wprowadzonym przez ustawodawcę w $\S 2$ art. 37 k.p.a. jest uzasadnienie, które ma zapobiegać nadużywaniu instytucji ponaglenia ${ }^{31}$. Strona ma obowiązek przytoczyć w uzasadnieniu okoliczności, które wskazują na istnienie bezczynności lub przewlekłości. Argumentacja co do poszczególnych form opieszałości musi odnosić się do legalnych definicji, co oznacza, iż musi wskazywać, że w ustawowym terminie nie rozstrzygnięto sprawy (w przypadku bezczynności) lub że organ podejmuje działania opieszale, tj. postępowanie trwa dłużej niż jest to niezbędne (w przypadku przewlekłości). Brak uzasadnienia należy uznać jako brak formalny, co powoduje konieczność wezwania do jego uzupełnienia pod rygorem pozostawienia ponaglenia bez rozpoznania (art. $64 \S 2$ k.p.a.). Za kolejny brak formalny trzeba uznać - w sytuacji podpisania ponaglenia przez pełnomocnika - niedołączenie dokumentu pełnomocnictwa, a także niewskazanie, jakiej sprawy i którego organu ponaglenie dotyczy ${ }^{32}$.

Również tryb wnoszenia ponaglenia jest odmienny względem istniejącego poprzednio trybu wnoszenia zażalenia. Ponaglenie w zakresie właściwości do jego rozpoznania nie zostało oparte na jednolitej konstrukcji prawnej w zakresie dewolutywności ${ }^{33}$. Ustawodawca

\footnotetext{
${ }^{28}$ Uzasadnienie..., Sejm VIII kadencji, druk sejmowy nr 1183.

${ }^{29}$ P. M. Przybysz, Kodeks postępowania administracyjnego..., op. cit., art. 37, nb. 6.

${ }^{30}$ B. Adamiak, J. Borkowski, Kodeks postępowania administracyjnego. Komentarz, Warszawa 2017, art. 37, nb. 7.

${ }^{31}$ Uzasadnienie..., Sejm VIII kadencji, druk sejmowy nr 1183.

${ }^{32}$ Ł. Sadkowski, Zmiany $w$ Kodeksie..., op. cit., s. 31.

${ }^{33}$ B. Adamiak, J. Borkowski, Kodeks postępowania administracyjnego. Komentarz, Warszawa 2017, art. 37, nb. 16.
} 
Jadwiga Kopeć - „Ponaglenie” - nowa instytucja w Kodeksie...

w art. 37 § 3 k.p.a. wyróżnił dwie sytuacje, z czego pierwszą uznał za zasadę, zaś drugą za odstępstwo od niej ${ }^{34}$. Za regułę uznany został pośredni tryb wnoszenia ponaglenia przewidziany w art. $37 \S 3$ pkt 1 k.p.a. Oznacza to, iż ponaglenie należy skierować do organu wyższego stopnia (w rozumieniu art. 17 k.p.a. lub przepisów szczególnych) za pośrednictwem organu prowadzącego postępowanie. W przypadku braku takiego organu, tzn. w razie, gdy nie ma w strukturze instancyjnej organu wyższego stopnia (np. w sprawach rozpoznawanych przez ministra lub Samorządowe Kolegium Odwoławcze) ponaglenie nie ma charakteru dewolutywnego. Jest ono kierowane bezpośrednio do organu prowadzącego postępowanie (art. $37 \S 3$ pkt 2 k.p.a.), co jest odstępstwem od pośredniego trybu wnoszenia ponaglenia. W przypadku, gdyby ponaglenie zostało skierowane do niewłaściwego organu, zastosowanie znajdzie dyrektywa z art. 65 k.p.a. Sama możliwość wniesienia ponaglenia nie została jednak ograniczona przez ustawodawcę terminem $^{35}$.

\section{Sposób rozpoznania ponaglenia wniesionego w trybie pośrednim}

Pośredni tryb wniesienia ponaglenia nakłada zarówno na organ prowadzący postępowanie jak i na organ wyższego stopnia właściwy do rozpoznania ponaglenia szereg obowiązków.

W celu zdyscyplinowania organu, któremu zarzuca się opieszałość ustawodawca wskazał, iż jest on zobowiązany przekazać ponaglenie organowi wyższego stopnia bez zbędnej zwłoki, nie później niż w terminie siedmiu dni od dnia jego otrzymania. Przekazanie ponaglenia obejmuje również dołączenie do niego niezbędnych akt sprawy oraz stanowiska organu prowadzącego postępowanie odnośnie podniesionych argumentów (art. 37 § 4 k.p.a.). Należy z tego wysnuć wniosek, iż nie jest konieczne przekazanie całości akt sprawy, a jedynie tych

\footnotetext{
${ }^{34}$ Uzasadnienie..., Sejm VIII kadencji, druk sejmowy nr 1183.

${ }^{35}$ B. Adamiak, J. Borkowski, Kodeks postępowania administracyjnego. Komentarz, Warszawa 2017, art. 37, nb. 11.
} 
dokumentów, które wskazują na przebieg postępowania ${ }^{36}$. Odpisy zaś mogą zostać sporządzone $\mathrm{w}$ formie dokumentu elektronicznego. Nie sposób więc nie zgodzić się z głosami prezentowanymi w literaturze ${ }^{37}$, iż możliwość przekazania odpisów zamiast oryginalnych akt sprawy należy uznać za racjonalne rozwiązanie. Celem takiej regulacji jest zapewnienie możliwości rozpoznania ponaglenia przez organ wyższego stopnia, przy jednoczesnym umożliwieniu kontynuacji postępowania przez organ je prowadzący ${ }^{38}$. Przekazanie bowiem całości akt do organu wyższego stopnia spowodowałoby wstrzymanie rozpoznawania sprawy, co tylko wydłużałoby czas potrzebny do jej rozstrzygnięcia.

Za dyskusyjne uważa się zaś uprawnienie organu do przesłania odpisów akt sprawy jedynie w niezbędnym zakresie. Wskazuje się, iż dopuszczenie takiego rozwiązania może negatywnie wpływać na ocenę całokształtu sprawy przez organ wyższego stopnia ${ }^{39}$. Wątpliwości te należy jednak odnosić do konkretnych sytuacji, gdyż z reguły wyodrębnienie akt wskazujących na przebieg postępowania nie powinno sprawiać problemów, zaś w przypadkach skrajnych, organ prowadzący postępowanie $\mathrm{w}$ razie niejasności może przekazać odpisy całych akt, by nie zaburzać obrazu całokształtu sprawy.

Obowiązek ustosunkowania się do argumentów zawartych w uzasadnieniu ponaglenia należy dodatkowo rozszerzyć o konieczność przedstawienia okoliczności rozpoznania i rozstrzygania sprawy ${ }^{40}$. Ustawodawca nie wskazał, w jaki sposób odpowiedź na ponaglenie ma zostać złożona, jednakże racjonalnym rozwiązaniem wydaje się być forma pisemna lub forma dokumentu elektronicznego ${ }^{41}$.

${ }^{36}$ P. M. Przybysz, Kodeks postępowania administracyjnego..., op. cit., art. 37, nb. 9.

${ }^{37}$ Por. np. J. Malanowski, [w:] M. Wierzbowski, A. Wiktorowska, Kodeks postępowania administracyjnego. Komentarz, Warszawa 2017, art. 37, nb. 2.

${ }^{38}$ Uzasadnienie..., Sejm VIII kadencji, druk sejmowy nr 1183.

${ }^{39}$ A. Kraczkowski, [w:] R. Hauser, M. Wierzbowski, Kodeks postępowania administracyjnego. Komentarz, Warszawa 2017, art. 37 nb. 7.

${ }^{40}$ B. Adamiak, J. Borkowski, Kodeks postępowania administracyjnego. Komentarz, Warszawa 2017, art. 37, nb. 15.

${ }^{41}$ A. Kraczkowski, [w:] R. Hauser, M. Wierzbowski, Kodeks postępowania administracyjnego. Komentarz, Warszawa 2017, art. 37 nb. 7. 
Jadwiga Kopeć - „Ponaglenie” - nowa instytucja w Kodeksie...

Organ wyższego stopnia po otrzymaniu ponaglenia ma siedem dni na jego rozpatrzenie (art. $37 \S 5$ k.p.a.). Co prawda ustawa nie wskazuje tego wprost, ale należy przyjąć, iż momentem rozpoczęcia biegu terminu jest otrzymanie ponaglenia wraz z niezbędnymi odpisami i stanowiskiem organu prowadzącego postępowanie. W przypadku braków organ rozpatrujący ponaglenie ma prawo zwrócić się do organu, któremu zarzuca się bezczynność lub przewlekłość, o nadesłanie brakujących dokumentów ${ }^{42}$. Nierozpatrzenie ponaglenia w przewidzianym przez ustawę terminie może narazić organ na zarzut bezczynności. Wynika to z faktu, że siedmiodniowy termin na załatwienie sprawy ma charakter terminu zawitego i nie ma możliwości jego przedłużania ${ }^{43}$. Warto podkreślić, iż przed nowelizacją organ rozpoznający zażalenie na bezczynność lub przewlekłość powinien był sprawę załatwić zgodnie z dyspozycją art. $35 \S 3$ k.p.a. tj. w terminie jednego miesiąca. Zatem nowelizacja wprowadziła w tym zakresie istotną zmianę, która ma zapewnić jak najszybsze rozpoznanie ponaglenia ${ }^{44}$.

Zmiana ustawy rozstrzygnęła także pojawiające się czasami wątpliwości co do formy załatwienia omawianej sprawy ${ }^{45}$. Formą rozstrzygnięcie organu wyższego stopnia w przedmiocie ponaglenia jest postanowienie, co zostało wskazane expressis verbis w art. $37 \S 6$ k.p.a. Wydane postanowienie powinno spełniać wszystkie formalne przesłanki wskazane w art. $124 \S 1$ k.p.a., a ponadto zawierać wszystkie szczegółowe elementy w zakresie merytorycznej treści postanowienia ${ }^{46}$. Bowiem na podstawie art. $37 \S 6$ k.p.a. organ rozpatrujący ponaglenie wydaje postanowienie, w którym po pierwsze wskazuje, czy organ rozpatrujący sprawę dopuścił się bezczynności lub przewlekłego prowadzenia postępowania, stwierdzając jednocześnie, czy miało miejsce rażące naruszenie prawa. Po drugie - w przypadku stwierdzenia

\footnotetext{
${ }^{42}$ 七. Sadkowski, Zmiany w Kodeksie..., op. cit., s. 32.

${ }^{43}$ A. Kraczkowski, [w:] R. Hauser, M. Wierzbowski, Kodeks postępowania administracyjnego. Komentarz, Warszawa 2017, art. 37 nb. 8.

${ }_{44}^{4}$ Uzasadnienie..., Sejm VIII kadencji, druk sejmowy nr 1183.

${ }^{45}$ Por. np. R. Kędziora, Kodeks postępowania administracyjnego. Komentarz, Warszawa 2014 , art. 37 , nb. 6 .

${ }^{46}$ B. Adamiak, J. Borkowski, Kodeks postępowania administracyjnego. Komentarz, Warszawa 2017, art. 37, nb. 19-20.
} 
bezczynności lub przewlekłości - musi zawrzeć dwa dodatkowe obowiązki wobec organu, którego działanie ocenia. Jeżeli postępowanie jest niezakończone to zobowiązuje organ rozpatrujący sprawę do załatwienia sprawy wyznaczając termin do jej załatwienia oraz zarządza wyjaśnienie przyczyn i ustalenie osób winnych bezczynności lub przewlekłości, a w razie potrzeby także podjęcie środków zapobiegających bezczynności lub przewlekłości w przyszłości.

Istotnym novum jest wprowadzenie możliwości zmiany treści postanowienia w zakresie wyznaczonego terminu zakończenia postępowania w sprawie. Na podstawie art. $37 \S 7$ k.p.a. organ rozpatrujący ponaglenie może z urzędu zmienić postanowienie, wyznaczając dłuższy termin zakończenia postępowania, jeżeli wyjdą na jaw istotne dla sprawy nowe okoliczności faktyczne lub nowe dowody, wymagające dłuższego postępowania, nieznane w momencie wyznaczania terminu. Przepis nie wskazuje wprost maksymalnej długości takiego terminu, co należy uznać jako pozostawienie tej kwestii w sferze uznania administracyjnego ${ }^{47}$. Wydłużając termin, organ musi mieć zawsze na uwadze zasadę szybkości postępowania administracyjnego (art. 12 k.p.a.).

\section{Sposób rozpoznania ponaglenia wniesionego w trybie bezpośrednim}

Wniesienie ponaglenia bezpośrednio do organu, który dopuszcza się bezczynności lub przewlekłości jest odstępstwem od reguły, co wynika z braku w strukturze instancyjnej organu wyższego stopnia (art. 37 $\S 3$ pkt. 2 k.p.a.).

Brak dewolutywności wymusił na ustawodawcy wprowadzenie odrębnych regulacji w zakresie rozpoznawania ponaglenia. Podstawową różnicą jest to, iż nie ma potrzeby przekazywania odpisów akt sprawy oraz stanowiska organu. Zastosowania nie znajdują również przepisy art. 37 § 6 i § 7 k.p.a. stanowiące o wydaniu i możliwości zmiany postanowienia, ponieważ jak wskazano w uzasadnieniu - organ, któremu

${ }^{47}$ A. Kraczkowski, [w:] R. Hauser, M. Wierzbowski, Kodeks postępowania administracyjnego. Komentarz, Warszawa 2017, art. 37 nb. 10. 
Jadwiga Kopeć - „Ponaglenie” - nowa instytucja w Kodeksie...

zarzuca się bezczynność lub przewlekłość nie powinien stawać się „,sędzią we własnej sprawie" 48 .

Wspólnym elementem pomiędzy trybem pośrednim i bezpośrednim jest termin rozpoznania ponaglenia - wynosi on siedem dni od momentu otrzymania ponaglenia (art. $37 \S 5$ k.p.a.). Zgodnie z treścią art. 37 $\S 8$ zd. 2 k.p.a. w przypadku stwierdzenia bezczynności lub przewlekłości organ prowadzący postępowanie niezwłocznie załatwia sprawę oraz zarządza wyjaśnienie przyczyn i ustalenie osób winnych bezczynności lub przewlekłości, a w razie potrzeby także podjęcie środków zapobiegających bezczynności lub przewlekłości w przyszłości.

$\mathrm{Z}$ bezpośredniego trybu wnoszenia i rozpoznawania ponaglenia wynikają jednak dwie negatywne konsekwencje dla strony. Po pierwsze w przypadku, gdy organ nie stwierdzi bezczynności lub przewlekłości, strona nie ma formalnej możliwości dowiedzenia się o tym, ponieważ organ nie ma obowiązku wydania w tym zakresie postanowienia ${ }^{49}$. Po drugie poprzez wyłączenie stosowania art. 37 § 6 k.p.a. ustawodawca zdjął z organu obowiązek ustalenia, czy miało miejsce rażące naruszenie prawa, co ogranicza możliwość wystąpienia $\mathrm{z}$ roszczeniem o odszkodowanie. Uzyskanie tej ochrony następuje poprzez wniesienie skargi na bezczynność lub przewlekłość do sądu administracyjnego ${ }^{50}$.

\section{Skutek wniesienia ponaglenia}

Złożenie ponaglenia jest warunkiem formalnym wniesienia do sądu skargi na przewlekłość lub bezczynność organu. Zgodnie bowiem z treścią art. 52 § 1 Prawa o postępowaniu przed sądami administracyjnymi ${ }^{51}$, skargę można wnieść po wyczerpaniu środków zaskarżenia, jeżeli służyły one skarżącemu w postępowaniu przed organem właściwym w sprawie. Jak wskazano w uzasadnieniu zmian, stanowisko wyrażane

\footnotetext{
${ }^{48}$ Uzasadnienie..., Sejm VIII kadencji, druk sejmowy nr 1183.

${ }^{49}$ Ł. Sadkowski, Zmiany w Kodeksie..., op. cit., s. 32.

${ }^{50}$ B. Adamiak, J. Borkowski, Kodeks postępowania administracyjnego. Komentarz, Warszawa 2017, art. 37, nb. 27.

${ }^{51}$ Ustawa z 30 sierpnia 2002 r. (tekst jedn. Dz.U. z 2017 r., poz. 1369 ze zm).
} 
w orzecznictwie Naczelnego Sądu Administracyjnego ${ }^{52}$ pozostaje aktualne w tym zakresie, iż skutek wniesienia środka zaskarżenia z art. 37 $\S 1$ k.p.a. wiąże się z samym jego wniesieniem, a nie z jego rozpatrzeniem przez organ. Zwrócono bowiem uwagę, iż skoro strona chce skorzystać ze środków ochrony przeciwko opieszałości organów, to należy doprowadzić do jak najszybszego załatwienia sprawy, bez wymagania od strony, by po złożeniu ponaglenia musiała oczekiwać na jego rozpoznanie bądź upływ określonego terminu ${ }^{53}$. Złożenie ponaglenia wywiera więc skutek wyczerpania przez stronę przysługujących jej środków zaskarżenia i otwiera drogę do złożenia skargi do sądu administracyjnego.

\section{Zmiany w obszarze pouczeń o prawie do wniesienia ponaglenia}

Istotną z punktu widzenia strony zmianą, o której warto wspomnieć, jest nałożenie na organ prowadzący postępowanie obowiązku pouczenia o sposobie i trybie wnoszenia ponaglenia (art. $36 \S 1$ k.p.a.). Organ musi tego dokonać w zawiadomieniu o niezałatwieniu sprawy w terminie. Dzięki temu strona nie będzie musiała samodzielnie pozyskiwać wiedzy, czy i w jaki sposób może kwestionować bezczynność lub przewlekłość organu ${ }^{54}$. Z drugiej strony niedopełnienie tego obowiązku będzie mogło mieć negatywny wpływ na całokształt oceny postępowania organu przez sąd administracyjny.

\section{Podsumowanie}

Sprawne i prawidłowe działanie organów administracji publicznej jest wskazywane każdorazowo jako cel kolejnych nowelizacji. Nie sposób nie zgodzić się z takimi zamiarami, ponieważ jednostka musi mieć zagwarantowane prawo do szybkiego i zgodnego z prawem

${ }^{52}$ Np. Postanowienie Naczelnego Sądu Administracyjnego z 25.02.2016 r., II OSK $326 / 16$, CBOSA.

${ }^{53}$ Uzasadnienie..., Sejm VIII kadencji, druk sejmowy nr 1183.

${ }^{54}$ Ł. Sadkowski, Zmiany w Kodeksie..., op. cit., s. 33. 
Jadwiga Kopeć - „Ponaglenie” - nowa instytucja w Kodeksie...

rozstrzygnięcia jej sprawy. Ponadto, jako podporządkowana strona stosunku administracyjnoprawnego, musi mieć dostęp do łatwych i zrozumiałych dla niej mechanizmów ochrony przed nieudolnym bądź opieszałym działaniem organów administracji publicznej. Takim środkiem, który ma zapewnić większą klarowność i spójność regulacji, a ponadto efektywność zaskarżania bezczynności lub przewlekłości jest ponaglenie.

Niewątpliwie wprowadzone regulacje wychodzą w pewnym stopniu naprzeciw oczekiwaniom doktryny i orzecznictwa. Z perspektywy jednostki, która chce dochodzić swoich praw są to zmiany pozytywne. Postępowanie w przedmiocie ponaglenia wydaje się nieskomplikowane i przejrzyste. Strona otrzymała gwarancje w postaci konieczności pouczenia jej o prawie do ponaglenia, a całe postępowanie obwarowane zostało terminami zawitymi dla organów.

Warto jednak zwrócić uwagę na nową sytuację, w której znalazły się organy administracji publicznej na skutek wprowadzenia instytucji ponaglenia. Nie ulega wątpliwości, iż ustawodawca nałożył na nie wiele nowych obowiązków, które muszą zostać wykonane w ustawowo określonych terminach.

Wobec tego takie rozwiązanie ma swoje plusy i minusy. Niewątpliwa poprawa pozycji jednostki wiąże się bowiem z szeregiem nowych zadań po stronie organu prowadzącego postępowanie. Zaś każdy nowy obowiązek skutkuje dodatkową pracą i wydłużeniem całego postępowania, a temu właśnie przeciwdziałać miało ponaglenie.

Dlatego odpowiedź na pytanie, czy ponaglenie rozwiąże problem opieszałości organów administracji publicznej pozostaje otwarte. Znalezienie bowiem optymalnego środka zapobiegającego bezczynności i służącego przyspieszeniu postępowań jest zadaniem trudnym. Wydaje się, że instytucja ponaglenia może być dobrym krokiem w tym kierunku. 


\section{Bibliografia:}

Adamiak B., Borkowski J., Kodeks postępowania administracyjnego. Komentarz, Wyd. C.H. Beck, Warszawa 2016.

Adamiak B., Borkowski J., Kodeks postępowania administracyjnego. Komentarz, Wyd. C.H. Beck, Warszawa 2017.

Błachucki M., Górzyńska T., Sibiga G., Analiza i ocena zmian kodeksu postępowania administracyjnego w latach 2010-2011, Wyd. Naczelny Sąd Administracyjny, Warszawa 2012.

Chróścielewski W., Opinia dotyczq̨ca projektu ustawy o zmianie ustawy - Kodeks postępowania administracyjnego oraz ustawy - Prawo o postępowaniu przed sądami administracyjnymi (druk sejmowy nr 2987), Biuro Analiz Sejmowych, niepubl. [opinia ta jest opublikowana na stronach Sejmu http://orka.sejm. gov.pl/rexdomk6.nsf/Opdodr?OpenPage\&nr=2987, [dostęp: 08-04-2018].

Gurba W., Zwalczanie i zapobieganie bezczynności oraz przewlekłości postępowania, „Państwo i Prawo” 2015, nr 11, s. 94-110.

Hauser R., Skoczylas A., Postępowania administracyjne i sq̨dowoadministracyjne z kazusami, Wyd. Wolters Kluwer, Warszawa 2016.

Hauser R., Wierzbowski M., Kodeks postępowania administracyjnego. Komentarz, Wyd. C. H. Beck, Warszawa 2015.

Hauser R., Wierzbowski M., Kodeks postępowania administracyjnego. Komentarz, Wyd. C.H. Beck, Warszawa 2017.

Kędziora R., Kodeks postępowania administracyjnego. Komentarz, Wyd. C. H. Beck, Warszawa 2014.

Kmieciak Z., Przewlekłość postępowania administracyjnego, „Państwo i Prawo” 2011, nr 6, s. 30-43.

Kmiecik Z., Kotulska M., Jeszcze o rodzajach opieszałości organów administracji publicznej w ogólnym postępowaniu administracyjnym, „Samorząd Terytorialny" 2017, nr 1-2, s. 94-108.

Miłosz M., Bezczynność organu administracji publicznej w postępowaniu administracyjnym, Wyd. Wolters Kluwer, Warszawa 2011.

Piątek W., Wezwanie do usunięcia naruszenia prawa w postępowaniu sądowoadministracyjnym, „Przegląd Sądowy” 2013, z. 9, s. 43-61.

Przybysz P. M., Kodeks postępowania administracyjnego. Komentarz, Wyd. Wolters Kluwer, Warszawa 2017.

Sadkowski Ł., Zmiany $w$ Kodeksie postępowania administracyjnego, Wyd. C. H. Beck, Warszawa 2017. 
Jadwiga Kopeć - „Ponaglenie” - nowa instytucja w Kodeksie...

Szalewska M., Bezczynność organu, a przewlekłość postępowania administracyjnego - o próbie rozróżnienia pojęć, „Administracja. Teoria-DydaktykaPraktyka" 2013, nr 3, s. 52-71.

Tarno J.P., Zażalenie i skarga na bezczynność organu (cz.1), „Fiskus 2006”, www.e-podatnik.pl/artykul/fiskus/8767/Zazalenie_i_skarga_do_sadu_administracyjnego_na_bezczynnosc_organu_cz_Ihtml [dostęp: 16-09-2017].

Wierzbowski M., Wiktorowska A., Kodeks postępowania administracyjnego. Komentarz, Wyd. C. H. Beck, Warszawa 2017. 